\title{
Optimization of Energy Performance of Windows by Applying Self-Adjustable Shadings
}

\author{
Vadim Starkov ${ }^{1}$, Petr Ovchinnikov ${ }^{1,}$ and Temur Dzampaev ${ }^{1}$ \\ ${ }^{1}$ Peter the Great St.Petersburg Polytechnical University, Polytecknycheskaya st., h. 29, St. \\ Petersburg, 195251, Russia
}

\begin{abstract}
The paper studied the thermo-physical properties of the windows with self-adjustable jalousie and consequent cooling load reduction for the buildings in 60-degree North latitude throughout the year. We focused on using different types of innovative materials and window structures and specified possible ways of improvement for modern and conservative windows. The paper discussed main factors that induce choosing specific window type. First, we investigated quantity of solar radiation energy that is taken into account while calculating the cooling load. Then this dependence was analyzed with different scenarios for specific window structures facing to corresponding cardinal direction. The results provide useful information for optimizing the thermal response of an enclosure to periodic solar heat gains.
\end{abstract}

\section{Introduction}

Fenestration has always been regarded as the weak element in the building envelope due to its role in determination of the energy balance of a building. At the same time, cooling performance is becoming a significant parameter for evaluating the energy performance of buildings [1]. Windows bring air and light into a room and connect the room with the world outside $[2,3]$.

This happens since thermal transmittance of the ordinary toughened glass is just 0.76 , $\left[\frac{W}{m^{2} K}\right]$, when the thickness of the glass is $6 \mathrm{~mm}$. Heat transfer coefficient of $6 \mathrm{~mm}$ thick ordinary toughened glass is $5.80,\left[\frac{W}{m^{2} K}\right]$. Even though heat transfer coefficient of the 24 $\mathrm{mm}$ thick low-emissivity insulating glass is $1.80,\left[\frac{W}{\mathrm{~m}^{2} \mathrm{~K}}\right]$, it is still much higher than the same coefficient for a simple wall with insulation layer [4,5].

\footnotetext{
*Corresponding author: pshenichca@hotmail.com
} 
Table 1. Thermophysical properties of glasses.

\begin{tabular}{|l|c|c|}
\hline Glass Type & U Value, $\left[\frac{\boldsymbol{W}}{m^{2} \boldsymbol{K}}\right]$ & Emissivity rate \\
\hline Single Clear Glass & 5.80 & 0.8400 \\
\hline Low E Single Glass & 3.70 & 0.0600 \\
\hline Low E Double Glazing & 1.80 & 0.0036 \\
\hline
\end{tabular}

Numerous experiments and building inspections clearly shows that the cause of the biggest thermal losses are window structures. Even if total area of windows in building is significantly lower than the area of walls, the share in total thermal losses usually lies in the rate of $25-40 \%$ [6]. The distribution of total thermal losses of a building during the heating season can be shown as following:

1. Losses through external walls $-23-25 \%$;

2. Losses through windows $-25-40 \%$;

3. Losses through infiltration - up to $40 \%$.

On the opposite side, during the cooling season window structures should operate without creating unreasonable heat gain in order to reduce possible negative influence on the air-conditioning system [4]. Thus, improving window structures can optimize overall energy performance of a building in demand for cooling and heating. A distinct improvement in comfort can be achieved by selecting a beyond-compliance solution to glazing for a new or retrofitted residential, commercial or institutional development. The main factors are dimensions, orientation of the windows, amount of shading and type of glass that is used.

\section{Determining of Solar Radiation Heat Influence}

The rigorous calculation of the cooling load due to solar heat gains through the glazing is quite complex, as it involves several phenomena [4]. Incident global solar radiation includes direct beam, sky, and ground-reflected radiation as it shown on the Figure 1.
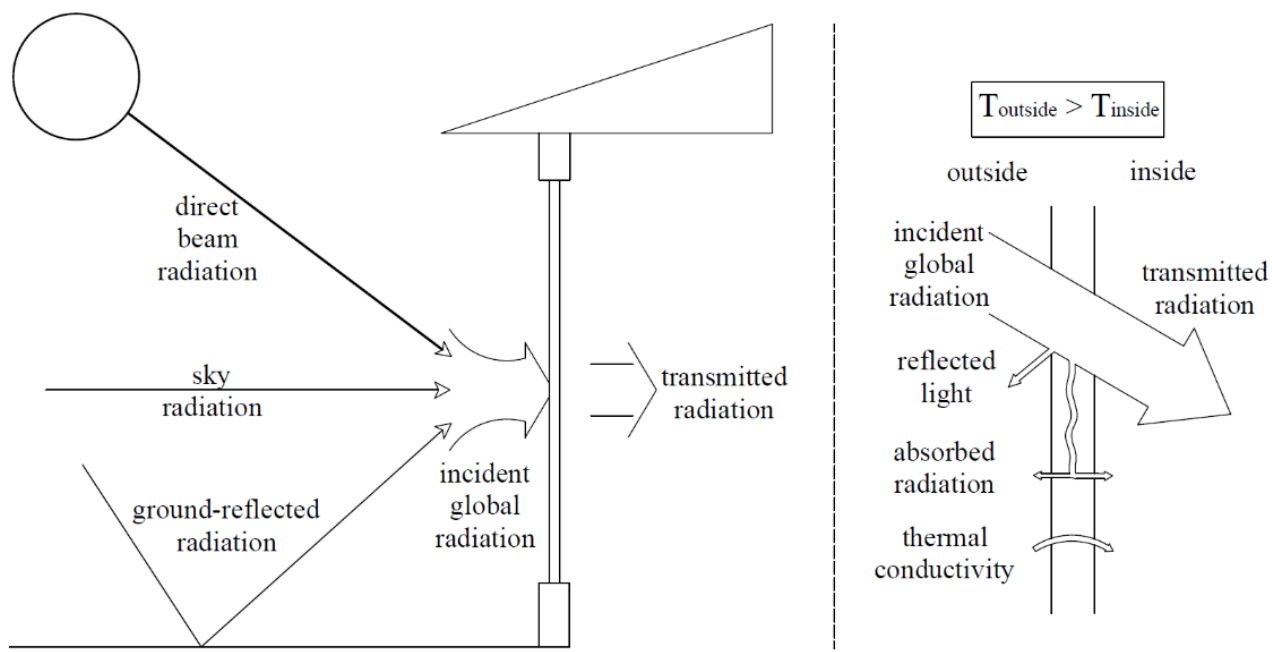

Fig. 1. Solar radiation and transmitting heating process. 
The solar radiation transmitted into a living space is less than the radiation that strikes the outside of a window, because of the losses associated with radiation reflected off and absorbed by the glass [7]. Transmitted radiation depends on the emissivity level that crucially differs for conventional single-glass window and modern low-e glass (that is shown in Table 1).

Ultimately, there are number of ways to improve energy performance of window structures, some of them are:

1. Low emissivity glass (low-E glass), has a high transmittance in the visible region, a high reflectance in the near infrared region and a low emittance in the far infrared region. It has been conventionally used in energy efficient windows because it not only prevents near infrared radiation (known as a source of heat) from penetrating the glass, but also blocks the emission of far infrared radiation of building interiors $[8,9]$.

2. Electrochromics (EC) are glazings whose optical transmittance can be controlled via a small applied electric potential. This is potentially useful in managing the admission of daylight into buildings, since they can be darkened when too much of it causes glare and be made lighter when more is needed to illuminate the interior space. With hourly blind position adjustments, electrochromics showes significantly higher $(62 \%$ and $53 \%$, respectively without and with overhang) lighting energy consumption than clear glass [1012].

3. Applying self-adjustable external or internal shadings or jalousie may also improve heat resistance of windows. Using these blinds in conventional way inside the building is less effective since they block solar radiation after it transmits through glazing. These blinds are more effective outside a building but cost of exploiting such a system is higher than of the same system that is placed in-between two layers of glass [13].

Furthermore, self-adjustable shadings in-between external and internal glasses may significantly improve conventional windows in achieving better results in energy performance during both heating and cooling season.

\section{Structure of a Window with Self-Adjustable Shading}

Construction of a window is more complex than of a wall. Window consists of light, sealing profile with chambers, insulation and gas. The typical width of window frame is $125 \mathrm{~mm}$. Free space between glasses is already being used for manually adjustable jalousie in a few European countries $[6,14]$ but putting this scheme together with automatization system, self-powered by solar radiation, we can get the structure, that is shown on the Figure 2. 

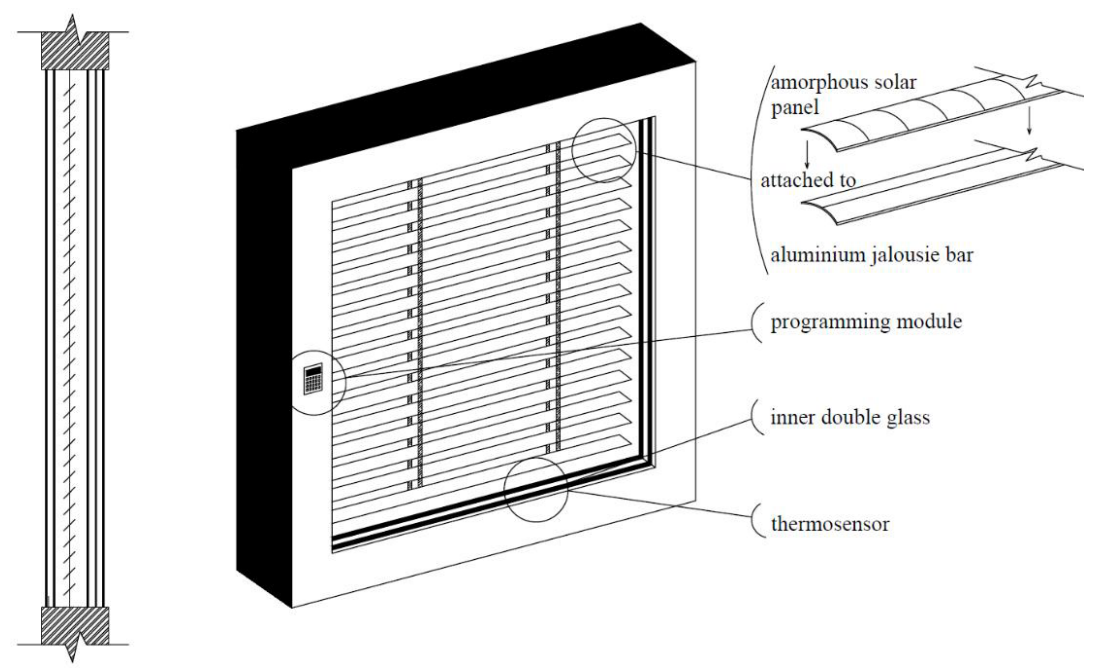

Fig. 2. Schematic image of the structure.

To make them self-adjustable we can attach amorphous solar panels to the jalousie bars, that will produce energy to meet the needs of the whole structure [15]. Jalousie can be adjusted with respect to temperature inside and outside which will be determined by two thermal sensors inside and outside of a frame. These panels will change their inclination to block extra heat gain or pass it free depending on temperature and irradiance. At the same time, the internal part of jalousie has to be covered with heat reflecting membrane to keep heat inside of a building during night times.

\section{Method of Determining the Energy Output and Heat Blocking Rate}

To estimate energy output of our system the following procedure was applied:

1. In order to assess the feasibility of solar installations the analyses of solar radiation has been conducted on the differently oriented surfaces with geographic $60^{\circ}$ North latitude [16]. Getting data of total radiant exposure $\mathrm{H},\left[\frac{W \cdot h}{m^{2}}\right][17]$, we can calculate irradiance rate $\mathrm{E},\left[\frac{w}{m^{2}}\right]$, for every month and cardinal direction using Formula 1:

$$
E=\frac{H}{t}
$$

where $\mathrm{t}$ - hours of daytime during the month, [h]. 
Table 2. Irradiance rate.

\begin{tabular}{|l|c|c|c|c|c|c|}
\hline \multirow{2}{*}{ Month } & \multirow{2}{*}{$\begin{array}{c}\text { Hours of } \\
\text { daytime, [h] }\end{array}$} & \multicolumn{5}{|c|}{ Irradiance on a vertical surface, $\left[\frac{W \cdot h}{m^{2}}\right]$} \\
\cline { 4 - 7 } & & N & NE/NW & E/W & SE/SW & S \\
\hline Jan & 6 & - & - & 102 & 371 & 505 \\
\hline Feb & 8 & - & - & 192 & 446 & 598 \\
\hline Mar & 8 & - & 133 & 347 & 617 & 734 \\
\hline Apr & 12 & 86 & 183 & 383 & 481 & 528 \\
\hline May & 18 & 91 & 163 & 272 & 323 & 294 \\
\hline Jun & 18 & 122 & 213 & 287 & 298 & 263 \\
\hline Jul & 18 & 109 & 179 & 276 & 285 & 272 \\
\hline Aug & 12 & 97 & 196 & 360 & 446 & 441 \\
\hline Sep & 12 & - & 139 & 275 & 428 & 469 \\
\hline Oct & 10 & - & 68 & 187 & 416 & 523 \\
\hline Nov & 8 & - & - & 125 & 342 & 475 \\
\hline Dec & 6 & - & - & 97 & 269 & 441 \\
\hline
\end{tabular}

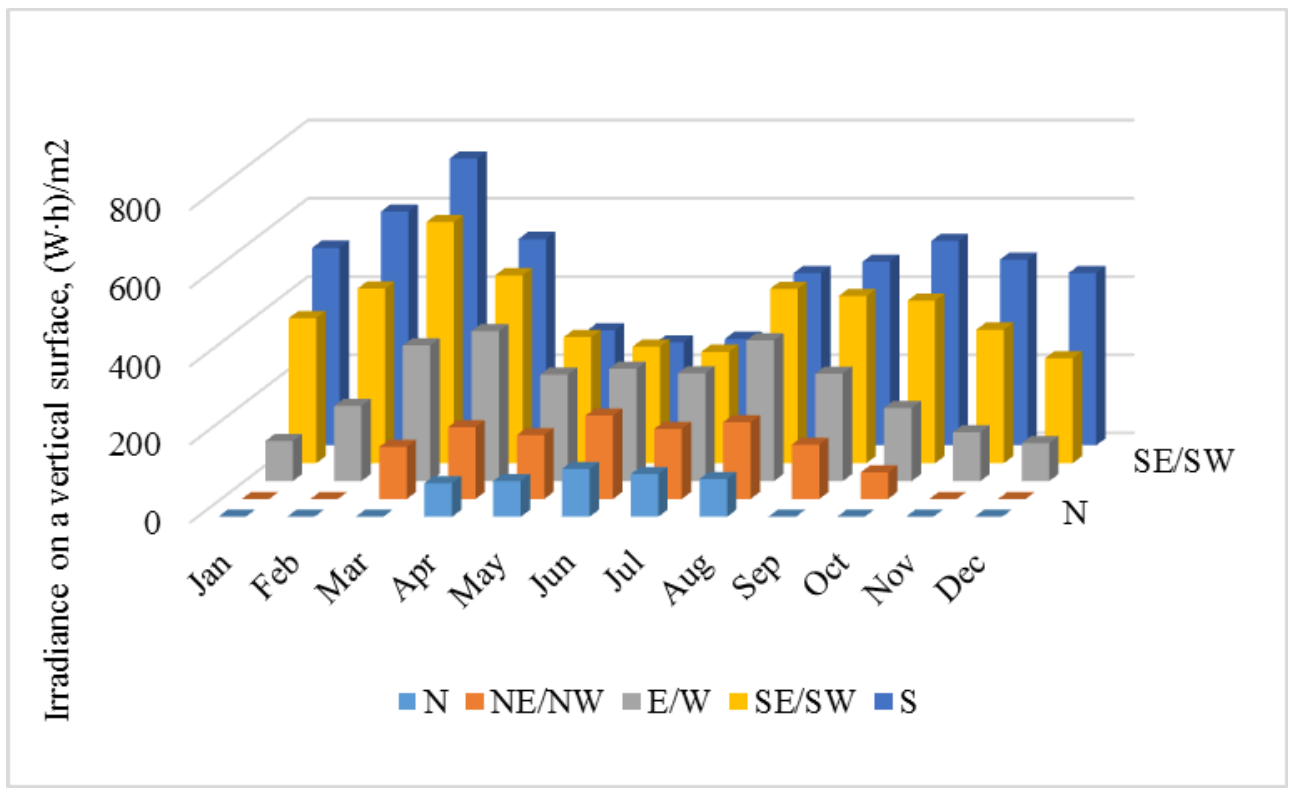

Diagram 1. Irradiance on a vertical surface.

2. The particular amorphous flexible solar panels made of steel foil and active ceramic membrane with the following characteristics were chosen:

a. dimensions of a panel are $180 \times 39,[\mathrm{~mm}]$;

b. voltage $1.5,[\mathrm{~V}]$; 
c. maximum output power for 1 element is 0.45 , [W].

Maximum output of a single solar panel, $[\mathrm{W}]$, depends on solar irradiance rate $\mathrm{E},\left[\frac{\mathrm{w}}{\mathrm{m}^{2}}\right]$, and can be shown on the Diagram 2 [18]:

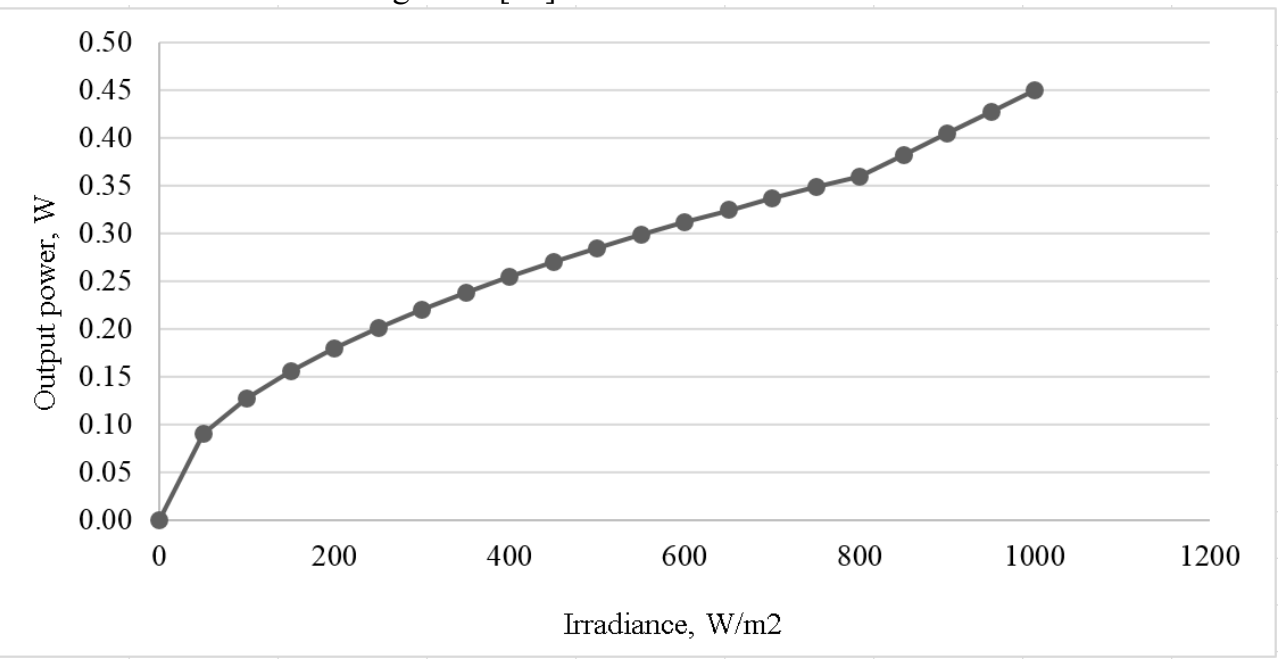

Diagram 2. Output power of solar panel.

According to the Diagram 2, if the irradiance rate is less than $800\left[\frac{W}{m^{2}}\right]$, the Formula 2 can be used for energy output of 1 vertical panel:

$$
P_{0}=\sqrt{0.000162 \cdot E} \cdot t
$$

where $P_{0}$ - output power for 1 solar panel per day, $[\mathrm{kW} \cdot h]$; E - average irradiance rate

per day,

$\mathrm{t}$ - number of daytime hours per day, [h].

Giving to emission rate of single clear glass at 0.84 data from the Diagram 1, Table 2 and Table 3, we can calculate mean output power for $1 \mathrm{~m}^{2}$ of solar panels. Since $1 \mathrm{~m}^{2}$ of panels consists of 142.45 panels, and they will be inclined by $45^{\circ}$. The Formula 3 is used:

$$
P=142.45 \sqrt{0.000162 \cdot E \cdot K \cdot 0.84} \cdot t,
$$

where $\mathrm{P}$ - output power for $1 \mathrm{~m}^{2}$ of solar panels per daytime, $[k W \cdot h]$; $\mathrm{K}-$ panel inclination coefficient, 0.84 - emissivity rate of a single glass.

To estimate the heat-blocking rate of the glazing we applied the following procedure:

1. the reflected solar heat for different types of structures was estimated by the Formula 4:

$=r \cdot E \cdot t$,

where R - reflected solar heat by $1 \mathrm{~m}^{2}$ of glazing, $\left[\frac{\mathrm{kw} \cdot \mathrm{h}}{\mathrm{m}^{2}}\right], \mathrm{r}-$ reflection coefficient.

2. To estimate the reflected solar heat by 1 square meter of simple glazing with jalousie Formula 4 is to be rewritten to the Formula 5: 


$$
R=0.16 \cdot E \cdot t+0.84 \cdot E \cdot t \cdot \sin (\alpha)
$$

where $\alpha$ - inclination of panels, 0.16 - reflection coefficient for simple glazing.

\section{Results and Discussion}

Accordingly, to $1 \mathrm{~m}^{2}$ of attached solar panels we can get the following numbers for the angle equal to $45^{\circ}$ [19].

Table 3. Mean output power for $1 \mathrm{~m}^{2}$ of solar panels per day ( $45^{0}$ inclination).

\begin{tabular}{|c|c|c|c|c|c|c|}
\hline \multirow{2}{*}{ Month } & \multirow{2}{*}{$\begin{array}{c}\text { Panel inclination } \\
\text { coefficient }\end{array}$} & \multicolumn{5}{|c|}{$\begin{array}{l}\text { Mean output power for } 1 \mathrm{~m}^{2} \text { of solar panels per } \\
\text { day }\left(45^{0} \text { inclination), }[W \cdot h]\right.\end{array}$} \\
\hline & & $\mathbf{N}$ & NE/NW & $\mathbf{E} / \mathbf{W}$ & SE/SW & $\mathbf{S}$ \\
\hline Jan & 0.835 & - & - & 92 & 175 & 205 \\
\hline Feb & 0.886 & - & - & 173 & 264 & 306 \\
\hline Mar & 0.996 & - & 153 & 247 & 330 & 359 \\
\hline Apr & 1.286 & 210 & 306 & 443 & 496 & 520 \\
\hline May & 1.537 & 355 & 474 & 612 & 666 & 636 \\
\hline Jun & 1.637 & 423 & 558 & 648 & 661 & 621 \\
\hline Jul & 1.600 & 396 & 506 & 629 & 639 & 624 \\
\hline Aug & 1.444 & 236 & 336 & 455 & 506 & 503 \\
\hline Sep & 1.215 & - & 259 & 364 & 455 & 476 \\
\hline Oct & 1.018 & - & 138 & 229 & 342 & 383 \\
\hline Nov & 0.896 & - & - & 141 & 233 & 274 \\
\hline Dec & 0.826 & - & - & 89 & 149 & 190 \\
\hline
\end{tabular}

Looking at the data from this table, we can notice the following:

1. System meets their demands in energy;

2. Applying this system on the northern facades is unreasonable;

3. Excess power can be used for the lighting system inside;

4. The most proper orientation in terms of gaining energy is south.

Applying Formula 5 we calculated the heat-blocking rate. The results are represented in the Table 4.

Table 4. Reflected solar heat by 1 square meter of glazing per day.

\begin{tabular}{|c|c|c|c|c|c|c|c|c|c|c|}
\hline \multirow{2}{*}{ Month } & \multicolumn{4}{|c|}{ Clear glass, $\left[\frac{\mathrm{kW} \cdot \mathrm{h}}{\mathrm{m}^{2}}\right]$} & \multicolumn{5}{c|}{ Low-e glass, $\left[\frac{\mathrm{kW} \cdot \mathrm{h}}{\mathrm{m}^{2}}\right]$} \\
\cline { 2 - 12 } & N & NE/NW & E/W & SE/SW & S & N & NE/NW & E/W & SE/SW & S \\
\hline Jan & - & - & 0.10 & 0.36 & 0.49 & - & - & 0.58 & 2.09 & 2.85 \\
\hline Feb & - & - & 0.25 & 0.57 & 0.77 & - & - & 1.44 & 3.36 & 4.50 \\
\hline Mar & - & 0.17 & 0.44 & 0.79 & 0.94 & - & 1.00 & 2.61 & 4.64 & 5.52 \\
\hline
\end{tabular}




\section{TPACEE-2016}

\begin{tabular}{|c|c|c|c|c|c|c|c|c|c|c|}
\hline \multirow{2}{*}{ Month } & \multicolumn{9}{|c|}{ Clear glass, $\left[\frac{\mathrm{kW} \cdot \mathrm{h}}{\mathrm{m}^{2}}\right]$} & \multicolumn{5}{c|}{ Low-e glass, $\left[\frac{\mathrm{kW} \cdot \mathrm{h}}{\mathrm{m}^{2}}\right]$} \\
\cline { 2 - 12 } & N & NE/NW & E/W & SE/SW & S & N & NE/NW & E/W & SE/SW & S \\
\hline Apr & 0.17 & 0.35 & 0.74 & 0.92 & 1.01 & 0.97 & 2.07 & 4.32 & 5.42 & 5.95 \\
\hline May & 0.26 & 0.47 & 0.79 & 0.93 & 0.85 & 1.55 & 2.76 & 4.61 & 5.46 & 4.97 \\
\hline Jun & 0.35 & 0.61 & 0.83 & 0.86 & 0.76 & 2.07 & 3.60 & 4.86 & 5.05 & 4.45 \\
\hline Jul & 0.32 & 0.52 & 0.80 & 0.82 & 0.79 & 1.85 & 3.03 & 4.67 & 4.82 & 4.61 \\
\hline Aug & 0.19 & 0.38 & 0.69 & 0.86 & 0.85 & 1.09 & 2.21 & 4.06 & 5.03 & 4.97 \\
\hline Sep & - & 0.27 & 0.53 & 0.82 & 0.90 & - & 1.57 & 3.10 & 4.83 & 5.30 \\
\hline Oct & - & 0.11 & 0.30 & 0.67 & 0.84 & - & 0.64 & 1.76 & 3.91 & 4.91 \\
\hline Nov & - & - & 0.16 & 0.44 & 0.61 & - & - & 0.94 & 2.57 & 3.57 \\
\hline Dec & - & - & 0.09 & 0.26 & 0.42 & - & - & 0.55 & 1.52 & 2.49 \\
\hline
\end{tabular}

Low-e glazing works efficiently during the cooling season, when no extra heating is required. During the heat season, the heat it reflects can be useful. By using adjustable jalousie we can improve the performance of the structure.

Table 5 shows the results of simple use of this automatic system - 45-degree closure during the cooling season and completely open during heating season. Even this simple method may improve the overall performance of glazing.

Table 5. Reflected solar heat by 1 square meter of glazing per day.

\begin{tabular}{|c|c|c|c|c|c|}
\hline \multirow{2}{*}{ Month } & \multicolumn{5}{|c|}{ Clear glass and jalousie, $\left[\frac{\mathrm{kW} / \mathrm{h}}{\mathrm{m}^{\mathbf{z}}}\right]$} \\
\cline { 2 - 6 } & $\mathbf{N}$ & $\mathbf{N E / N W}$ & $\mathbf{E} / \mathbf{W}$ & $\mathbf{S E} / \mathbf{S W}$ & $\mathbf{S}$ \\
\hline Jan & - & - & 0.098 & 0.356 & 0.485 \\
\hline Feb & - & - & 0.246 & 0.571 & 0.766 \\
\hline Mar & - & 0.170 & 0.444 & 0.790 & 0.939 \\
\hline Apr & 0.165 & 0.352 & 0.736 & 0.923 & 1.013 \\
\hline May & 1.240 & 2.213 & 3.697 & 4.378 & 3.989 \\
\hline Jun & 1.659 & 2.890 & 3.896 & 4.046 & 3.569 \\
\hline Jul & 1.484 & 2.432 & 3.746 & 3.867 & 3.697 \\
\hline Aug & 0.876 & 1.775 & 3.259 & 4.037 & 3.989 \\
\hline Sep & - & 1.257 & 2.488 & 3.870 & 4.247 \\
\hline Oct & - & 0.108 & 0.299 & 0.666 & 0.836 \\
\hline Nov & - & - & 0.160 & 0.437 & 0.608 \\
\hline Dec & - & - & 0.093 & 0.258 & 0.423 \\
\hline
\end{tabular}

Higher heat blocking during summer could be achieved. Table 6 shows the difference between heat reflected by clear glass and the system with jalousie within a day. The calculation Formula 6 is used: 


$$
\Delta=R_{1}-R_{2}
$$

where $R_{1}$ - reflected solar heat by 1 square meter of clear glass and jalousie per day, $\left[\frac{\mathrm{kw} \cdot \mathrm{h}}{\mathrm{m}^{2}}\right] ; \mathrm{R}_{2}$ - reflected solar heat by 1 square meter of clear glass per day, $\left[\frac{\mathrm{kw} \cdot \mathrm{h}}{\mathrm{m}^{2}}\right]$;

Table 6. Blocking rate of transmitted solar radiation.

\begin{tabular}{|c|c|c|c|c|c|}
\hline \multirow{2}{*}{ Month } & \multicolumn{5}{|c|}{ Difference between reflected solar heat in accordance with surface orientation, } \\
\cline { 2 - 6 } & N & NE/NWh & E/W & SE/SW & S \\
\hline May & 0.977 & 1.744 & 2.912 & 3.449 & 3.142 \\
\hline Jun & 1.307 & 2.277 & 3.069 & 3.188 & 2.811 \\
\hline Jul & 1.169 & 1.916 & 2.951 & 3.046 & 2.912 \\
\hline Aug & 0.690 & 1.399 & 2.567 & 3.181 & 3.142 \\
\hline Sep & - & 0.990 & 1.960 & 3.049 & 3.346 \\
\hline
\end{tabular}

Due to reduction of transmitting solar heat by $73.5 \%$, cooling load decreases by $24 \%$. The total improvement depends on specific dimensions and parameters of room.

Using advanced approaches, simulation of a computer model or construction of a prototype combined with thermography [20], may entail even higher result. Analyses provided by P. Pfrommer [21] can also be applied for more elaborated results.

\section{Conclusion}

Series of studies have been made, and according to data presented in the article, the following statements were proposed:

1. self-adjustable heat-blocking jalousie on the base of solar panels are feasible;

2. extra solar energy gained by solar panels may be used for powering inner light;

3. the most proper orientation for this system, in terms of gaining energy, is south;

4. using low-e glass is more effective way to block solar heat but it cause unreasonable heat blocking during the heating season;

5. applying self-adjustable heat-blocking jalousie with low-e glass improve heat blocking up to $0.38 \%$, that can not be considered as an effective combination;

6. the most effective way of exploiting this system is to combine it with clear glass that would decrease cooling load by $24 \%$;

7. total transmitted solar heat blocking rate for the system is $73.5 \%$ for combining with clear glass and approximately $98 \%$ for combining with low-e glass.

\section{References}

1. K. Tsikaloudaki, K. Laskos, T. Theodosiou, D. Bikas, Energy and Buildings, 49, $192-$ 199 (2012)

2. V. Murgul, N. Vatin, I. Zayats, Procedia Engineering, 117, 824-829 (2015)

3. M. Tanic, D. Stankovic, V. Nikolic, M. Nikolic, D. Kostic, A. Milojkovic, S. Spasic, N. Vatin, Procedia Engineering, 117, $924-937$ (2015)

4. G. Evola, L. Marletta, Applied Energy, 160, 431-441 (2015) 
5. Z. Huifen, F. Yingchao, Y. Fuhua, T. Hao, Z. Ying, Mathematical Problems in Engineering, 1-9 (2013)

6. V.N. Starkov, Povyshenie energoeffektivnosti zdaniy $i$ sooruzheniy (SPBSTU, St.Petersburg, 2014)

7. W. Marion, S. Wilcox, Solar radiation data manual for buildings (NREL, 1995)

8. A. Jonsson, A. Roos, Solar Energy, 84, 1370-1375 (2010)

9. J. Qu, J. Song, J. Qin, Z. Song, W. Zhang, Energy and Buildings, 77, 1-10 (2014)

10. R. Baetens, B.P. Jelle, A. Gustavsen, Solar Energy Materials and Solar Cells, 94, 87105 (2010)

11. L.L. Fernandes, E.S. Lee, G. Ward, Energy and Buildings, 61, 8-20 (2013)

12. B.P. Jelle, Solar Energy Materials and Solar Cells, 116, 291-323 (2013)

13. B. Anderson, Solar energy: fundamentals in building design (Total Environmental Action, 1977)

14. G. Nair, K. Mahapatra, L. Gustavsson, Applied Energy, 89, 329-338 (2012)

15. S. Guha, J. Yang, High-Efficiency Amorphous Silicon Alloy Based Solar Cells and Modules, 130, (2005)

16. G. Radović, V. Murgul, M. Cvetkovska, E. Aronova, N. Vatin, Journal of Applied Engineering Science, 12, 277-284 (2014)

17. SP 131.13330.2012 Stroitel'naya klimatologiya (aktualizatsiya SNiP 23-01-99) (SR 131.13330.2012 Building Climatology)

18. M. Pagliaro, G. Palmisano, R. Ciriminna, Flexible Solar Cells (WILEY-VCH Verlag $\mathrm{GmbH} \&$ Co. KGaA, Weinheim, 2008)

19. W. Beckman, J. Duffie, S. Klein, Simulation of solar heating systems (ASHRAE GRP N.Y., 1977)

20. G. Baldinelli, F. Bianchi, Applied Energy, 136, 250-258 (2014)

21. P. Pfrommer, K.J. Lomas, C. Seale, Chr. Kupke, Solar Energy, 54, 287-299 (1995) 